\title{
PENGEMBANGAN APLIKASI PEMODELAN COSPLAY DENGAN TEKNOLOGI VIRTUAL REALITY BERBASIS ANDROID
}

\section{Developing Application for Cosplay Modeling with Android Based Virtual Reality Technology}

\author{
Mariana Gracia, mariaa.mariana05@ kalbis.ac.id ${ }^{1)}$, Ester Lumba, \\ ester.lumba@kalbis.ac.id ${ }^{2}$ \\ ${ }^{122)}$ Informatika/Departemen Industri Kreatif, Kalbis Institute
}

\begin{abstract}
This research is aimed to create an application of $3 D$ cosplay modeling by using Virtual Reality (VR) technology. The application is used by the visitors of Japan Festival, both cosplayer and the noncosplayer. Therefore, it consists of three menus which are the display of the cosplay room menu, mix and match costumes for male and female menu, and cosplay description menu. The researcher develops this application with Interactive Multimedia System of Design and Development (IMSDD) method. The developing of this application uses Blender and Unity3D. Conclusively, the result of this research is Android based application with APK file format that is used in smartphones with its Gyroscope sensor and Android 4.4 KitKat minimum operating system.
\end{abstract}

Keywords: Android, Blender, Cosplay IMSDD, Unity3D, Virtual Reality

\begin{abstract}
ABSTRAK
Tujuan penelitian ini untuk menghasilkan aplikasi pemodelan $3 D$ cosplay dengan menggunakan teknologi Virtual Reality (VR). Aplikasi digunakan oleh pengunjung festival Jepang, baik cosplayer maupun bukan cosplayer. Aplikasi terdiri dari tiga menu yaitu menu untuk masuk ke ruangan display cosplay, menu mix \& match kostum untuk laki-laki dan perempuan, serta menu untuk penjelasan mengenai cosplay. Peneliti mengembangkan aplikasi menggunakan metode Interactive Multimedia System of Design and Development (IMSDD). Pengembangan aplikasi menggunakan Blender dan Unity3D. Hasil dari penelitian ini adalah aplikasi berbasis Android dengan format file APK yang dijalankan pada telepon pintar dengan sensor Gyroscope dan sistem operasi minimum Android 4.4 KitKat.
\end{abstract}

.Kata Kunci: Android, Blender, Cosplay IMSDD, Unity3D, Virtual Reality

\section{PENDAHULUAN}

Cosplay atau costume play berawal populer di Jepang dan Amerika, namun saat ini cosplay semakin diminati oleh masyarakat Indonesia, hal ini karena cosplay memiliki keunikan tersendiri yaitu dengan menggunakan kostum, aksesoris, dan rias wajah seperti tokoh-tokoh dalam game, manga, anime, film kartun, cerita dongeng dan musisi idola. Selain itu, cosplay juga dapat digunakan untuk semua umur, mulai dari kalangan anak-anak, remaja sampai kalangan dewasa.

Japan Fest (J-Fest) atau festival Jepang merupakan pameran dan acara yang berkaitan dengan Jepang seperti anime, manga, cosplay, game serta musiknya. Pada festival Jepang ini, tersedia beberapa stand untuk menampilkan maupun menjual 
produk yang berkaitan dengan Jepang. Peneliti pun selalu berpartisipasi dalam festival ini untuk mengenalkan dan menjual kostum dan aksesoris yang berkaitan dengan cosplay serta merchandise anime. Namun, peneliti tidak dapat menampilkan variasi kostum, karena peneliti juga harus membawa merchandise anime, padahal variasi kostum cosplay itu banyak. Peneliti tidak dapat menampilkan banyak kostum karena keterbatasan tempat, letak lokasi pameran yang jauh serta keterbatasan biaya, padahal banyak pengujung yang berdatangan untuk mengenal mengenai cosplay. Selain itu, pengunjung juga tertarik dengan cosplay original character dimana mereka dapat menentukan kostumnya sendiri.

Peneliti memiliki gagasan dengan menggunakan teknologi virtual reality. Teknologi virtual reality telah banyak digunakan di berbagai bidang seperti hiburan, pendidikan, kesehatan maupun untuk penjualan. Peneliti memanfaatkan teknologi virtual reality untuk membuat aplikasi dimana pengguna nya dapat melihat model kostum secara 3D dengan menggunakan model karakter anime yang sesuai dengan kostum tersebut. Aplikasi juga memberikan informasi mengenai nama karakter dan judul film dari kostum tersebut dan mengenai cosplay, pengguna juga dapat melakukan kostumisasi atau mix and match kostumnya untuk original character atau karakter tertentu.

Pengembangan aplikasi pemodelan cosplay virtual reality berbasis android ini digunakan untuk pameran atau festival Jepang dalam mengenalkan toko Celestine shoppu dan cosplay kepada pengujung sehingga peneliti dapat menampilkan kostum dan informasi mengenai kostum tersebut, selain itu, pengujung juga dapat mencoba mix and match untuk kostum original character menggunakan teknologi virtual reality.

\section{METODOLOGI PENELITIAN}

Penelitian dilakukan untuk menghasilkan sebuah aplikasi pemodelan 3D cosplay dan aplikasi mix and match kostum pada pameran atau festival Jepang menggunakan teknologi virtual reality. Penelitian ini dilakukan pada toko "Celestine Shoppu" yang merupakan bisnis cosplay yang dimiliki oleh peneliti sendiri, dimana cosplay merupakan bentuk penyaluran hobi dalam menggunakan kostum, properti, aksesoris dan make up sehingga menjadi mirip dengan karakter anime, film, kartun, komik, dan video game dengan adanya gerakan yang dilakukan oleh karakter tersebut, dan cosplay original character adalah jenis cosplay yang berasal dari keinginan atau style sendiri sehingga karakter yang diperankan tidak berasal dari anime, film, kartun atau video game [1].

Di dalam pengembangannya, aplikasi akan menggunakan sudut pandang pengguna dengan bantuan teknologi virtual reality, dimana di stand festival peneliti akan menyediakan kacamata VR sehingga pengujung festival dapat melihat visualisasi lingkungan, model karakter anime dan kostum cosplay.

Seperti pada gambar 1, peneliti melakukan pengamatan atau observasi terlebih dahulu setiap peneliti membuka stand pada festival atau pameran Jepang. Pada saat festival Jepang tersebut, peneliti menemukan beberapa masalah seperti mengenai tempat stand yang terlalu kecil sehingga kostum yang ditampilkan hanya sedikit padahal pengunjung ingin melihat kostum tersebut, banyak pengunjung yang ingin mengenal cosplay dan sering bertanya mengenai karakter dari kostum yang ditampilkan, namun peneliti tidak dapat menjelaskan satu per satu ke pengunjung karena keterbatasan waktu dan tenaga, selain itu pengunjung tidak memiliki sarana atau sulit dalam melakukan mix \& match kostum untuk cosplay original character. 
Dari persoalan tersebut, peneliti melakukan identifikasi masalah dan menggunakan kajian pustaka untuk mendukung penelitian dan proses pengembangan aplikasi, kemudian peneliti mengembangkan aplikasi pemodelan cosplay 3D dan mix match kostum cosplay. Pengembangan aplikasi menggunakan metode Interactive Multimedia System Design and Development (IMSDD) yang terdiri dari identifikasi kebutuhan sistem, perancangan, implementasi dan evaluasi. Setelah aplikasi telah selesai dibuat, hasil atau keluaran dari pengembangan aplikasi yaitu dalam bentuk format android package (.apk) yang kemudian di instal pada telepon pintar android. Aplikasi diuji menggunakan pengujian user experience dimana aplikasi diuji oleh pengunjung festival Jepang (cosplayer maupun bukan cosplayer). Lalu, dari hasil pengujian tersebut, peneliti mendapatkan umpan balik dan saran dari pengguna.

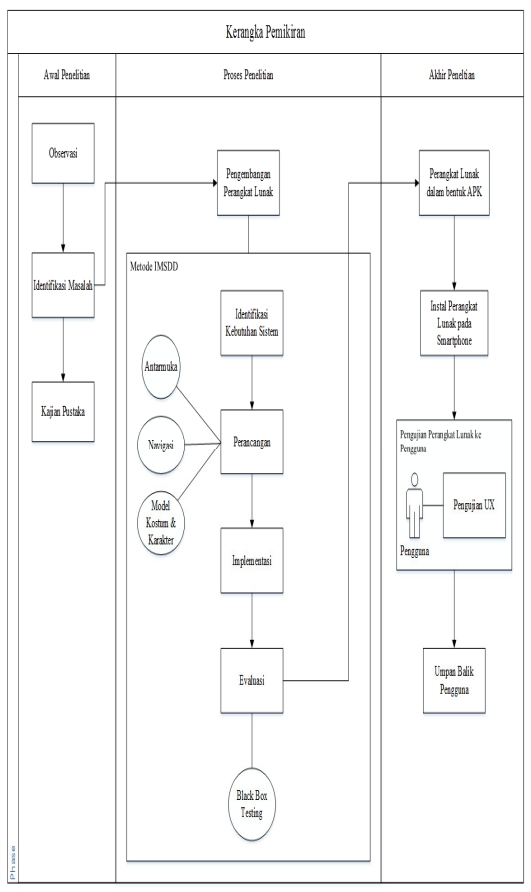

Gambar 1. Kerangka Pemikiran
Dalam proses pengembangan aplikasi ini, peneliti menggunakan metode Interactive Multimedia System Design and Development (IMSDD). Metode tersebut merupakan metode pengembangan perangkat lunak yang mengimplementasikan multimedia interaktif [2].

Tahapan pengembangan aplikasi pada metode IMSDD yaitu:

\section{Identifikasi Kebutuhan Sistem}

Tahapan ini dilakukan untuk mengidentifikasi kebutuhan pengguna dan sistem. Pada tahap ini, peneliti mendefinisikan tujuan sistem, menentukan pengguna aplikasi dan kebutuhan yang diperlukan oleh pengguna, serta menentukan perangkat lunak (software) dan perangkat keras (hardware) yang digunakan.

Aplikasi digunakan oleh pengunjung festival Jepang yang terdiri dari cosplayer dan pengunjung biasa (bukan cosplayer). Selain itu, aplikasi digunakan pada ponsel pintar Android dengan sistem operasi minimal Kit Kat dan memiliki sensor Gyroscope. Dalam penggunaannya, aplikasi hanya digunakan oleh single user dan menggunakan sudut pandang orang pertama dengan teknologi virtual reality, sehingga pengguna dapat melihat visualisasi lingkungan toko dan kostum cosplay pada aplikasi.

Pengembangan aplikasi memiliki kebutuhan pengembang yaitu sebagai mana ditunjuk oleh Tabel 1 ..

Tabel 1. Kebutuhan perangkat keras dan lunak pengembangan

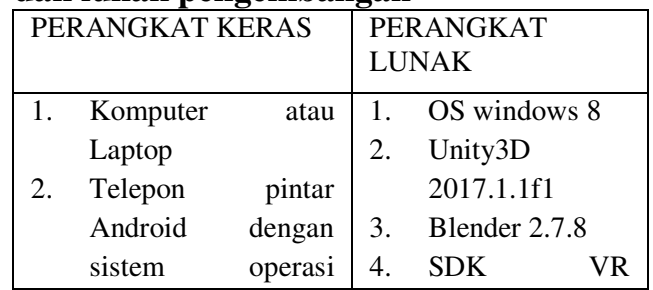




\begin{tabular}{|ll|lr|}
\hline & minimum Android & & \multicolumn{2}{l|}{ (GoogleVR) } \\
& $\begin{array}{l}\text { untuk Unity3D } \\
\text { memiliki Gyroscope }\end{array}$ \\
3. & Google Cardboard & Android SDK & r25.2.5 dan \\
4. & $\begin{array}{l}\text { Controller VR / } \\
\text { Joystick }\end{array}$ & JDK 1.8.0 171 \\
& & & \\
\hline
\end{tabular}

Pengembangan aplikasi ini memiliki kebutuhan pengguna, yaitu sebagai mana ditunjuk oleh tabel 2 ..

\section{Tabel 2. Kebutuhan perangkat keras} dan lunak untuk pengguna

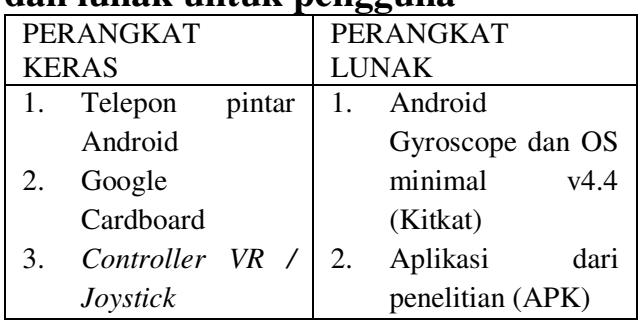

2. Pertimbangan Rancangan

Tahapan ini terdiri dari metafora desain yaitu menentukan model sebagai desain interface aplikasi, jenis dan format informasi yaitu untuk menentukan jenis informasi yang dibutuhan pada aplikasi, struktur navigasi yang digunakan untuk menyusun strategi navigasi yang jelas.

Pada tahap desain interface, peneliti menentukan lingkungan virtual yang digunakan, maka interface yang digunakan adalah lingkungan yang toko cosplay dengan adanya karakter anime sebagai manekin yang menggunakan kostum. Aplikasi juga menampilkan informasi mengenai cosplay. Selain itu untuk menu mix and match kostum, terdapat tampilan manekin tanpa menggunakan kostum, disini pengguna dapat melakukan mix and match kostum dari pilihan pakaian atasan dan bawahan perempuan dan laki - laki yang telah disediakan aplikasi.

Pada tahap ini, peneliti menentukan informasi yang digunakan pada pengembangan aplikasi yaitu teks, gambar, dan asset. Asset digunakan sebagai objek untuk membuat lingkungan toko cosplay, karakter anime dan kostumnya. Teks digunakan untuk memberikan informasi atau keterangan aplikasi. Gambar atau image digunakan untuk mendukung informasi yang diberikan.

Tahap selanjutnya yaitu membuat flowchart atau alur dari aplikasi pemodelan cosplay, yaitu sebagai berikut:

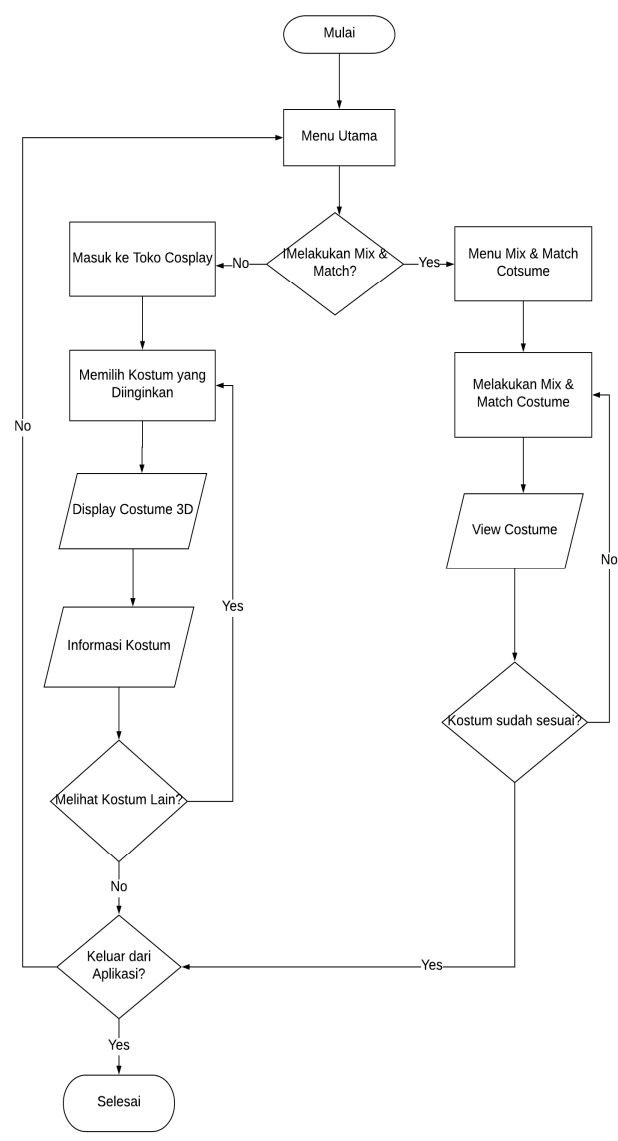

\section{Gambar 2. Diagram Alur Penggunaan Aplikasi}

Seperti pada gambar 2, halaman awal yang tampil pada aplikasi yaitu menu utama, pada menu utama terdapat informasi mengenai aplikasi, toko, dan tombol untuk menuju ke scene lain, fitur utama pada aplikasi adalah menu display costume atau 
masuk ke toko dan menu mix \& match kostum. Jika pengguna ingin melakukan mix \& match kostum maka menuju ke menu mixmatch, pengguna melakukan mix \& match kostum dengan memilih pakaian atasan dan bawahan sampai kostum sesuai keinginan pengguna, jika sudah selesai pengguna dapat keluar dari menu mixmatch dan menuju ke menu utama. Jika pengguna ingin melihat kostum di dalam toko maka menuju ke menu display, pengguna dapat memilih melihat kostum dan karakter anime 3D serta informasi kostum yang diinginkan dan jika pengguna ingin melihat kostum lain, pengguna dapat berjalan di dalam toko dan memilih karakter atau kostum yang diinginkan. Jika sudah selesai melihat kostum dan karakter yang tersedia, pengguna dapat keluar dari menu display dan menuju ke menu utama.

Kemudian struktur navigasi ini digunakan untuk melihat struktur atau alur pada aplikasi. Berikut adalah perancangan struktur navigasi aplikasi pemodelan cosplay:

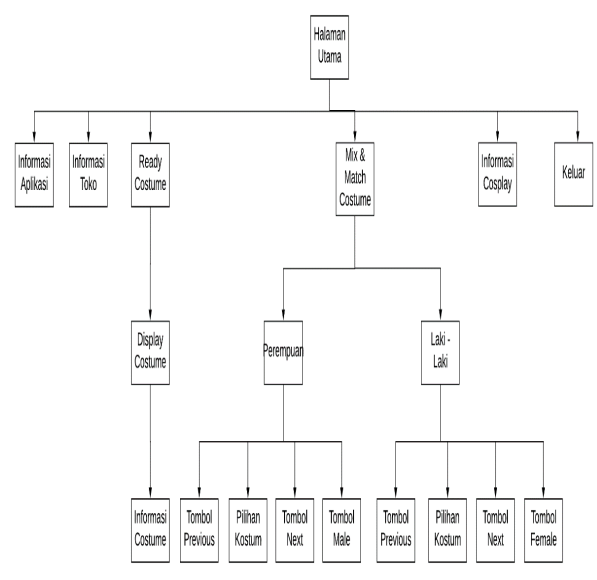

Gambar 3. Struktur Navigasi

Pada halaman utama terdapat informasi mengenai toko dan aplikasi, kemudian terdapat tombol display, tombol mix \& match, dan tombol exit. Tombol display digunakan untuk menuju ke menu dimana pengguna dapat melihat kostum yang tersedia (ready costume) pada toko dan informasi mengenai kostum dan karakter anime tersebut, tombol mix \& match untuk menuju ke menu mix \& match kostum untuk laki - laki dan perempuan, pada menu mix \& match perempuan terdapat pilihan kostum, tombol previous untuk ke pakaian sebelumnya, tombol next digunakan untuk ke pakaian selanjutnya, dan tombol male digunakan untuk ke menu mix \& match laki-laki, pada menu mix \& match laki - laki terdapat juga tombol previous, tombol next, dan tombol female digunakan untuk menuju ke mix \& match perempuan. Tombol exit digunakan untuk keluar dari aplikasi.

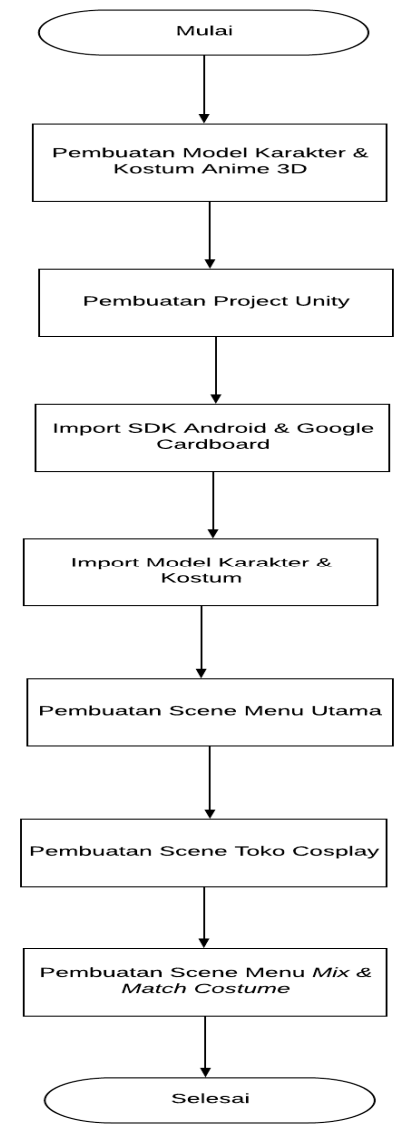

\section{Gambar 4. Alur Pengembangan Aplikasi}

\section{Implementasi}

Pada tahap ini, peneliti melakukan pembuatan aplikasi sesuai dengan rancangan yang telah dibuat. Tahapan ini 
terdiri dari pembuatan model karakter dan kostum anime, pembuatan projek Unity, import SDK Android dan Google Cardboard, import model karakter dan kostum ke Unity, pembuatan scene menu utama, scene toko cosplay dan scene menu mix and match costume.

Pembuatan model karakter dan kostum anime 3D menggunakan Blender, Blender merupakan perangkat lunak open source visualisasi 3D yang digunakan untuk membuat pembuatan model 3D, animasi dan pengguna dapat membuat sebuah game dengan game engine yang ada pada software ini [3]. Terdapat 7 model karakter anime dan kostum perempuan dan 6 model karakter anime dan kostum laki-laki yang telah dibuat, berikut adalah salah satu contoh model karakter anime dan kostumnya:

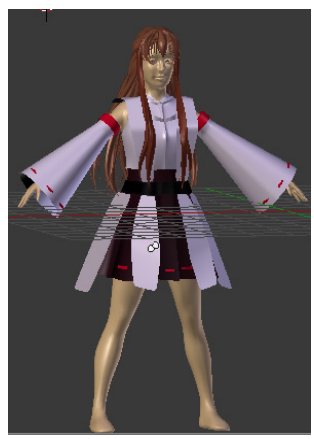

\section{Gambar 5. Model Karakter Anime dan Kostum}

Pembuatan projek menggunakan Unity 3D, Unity 3D merupakan perangkat lunak untuk pengembangan video game (game engine), visualisasi arsitektur, dan media interaktif dengan pemodelan 3D [4]. Aplikasi dijalankan pada android, maka diperlukan import SDK, JDK dan Google Cardboard (GoogleVR), sdk android yang digunakan r25.2.5 dan jdk 1.8.0_171.

Pembuatan scene menu utama menggunakan button, canvas dan image pada unity. Penambahan dilakukan pada $t a b$ hierarchy di unity. Canvas yang dibutuhkan untuk menampilkan menu utama, penjelasan tentang Celestine shoppu dan aplikasi. Kode program untuk melakukan pindah scene menggunakan LevelManager yang merupakan public class yang berisi class ChangeLevel dengan adanya string levelName, pada class tersebut berisi SceneManager.LoadScene yang digunakan untuk code pindah scene dan LoadSceneMode.Single digunakan agar scene yang ditampilkan tidak bertumpuk sehingga hanya menampilkan satu scene. Pada setiap tombol ditambahkan event onClick() dengan klik “+”, kemudian pilih LevelManager untuk memasukkan script ke button. Berikut adalah hasil dari pembuatan scene menu utama.

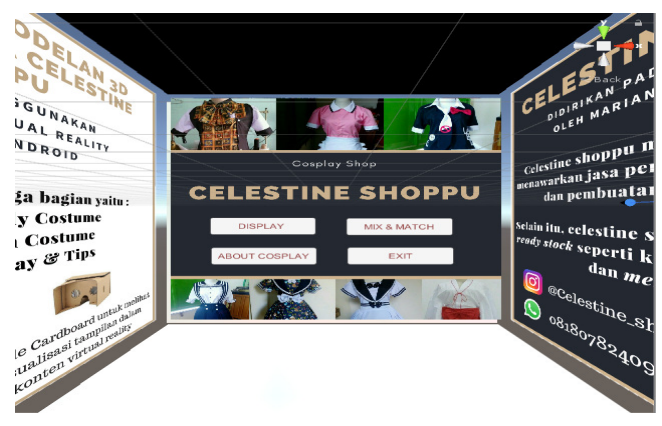

Gambar 6. Scene Menu Utama

Pembuatan scene toko cosplay menggunakan asset yang terdapat pada situs Unity Asset Store, setelah asset diunduh, peneliti merancang ruangan toko cosplay dengan menggunakan asset tersebut, asset dapat diatur posisi dan ukuran sesuai kebutuhan. Ketika masuk ke scene toko cosplay, pengguna sebagai sudut orang pertama (First Person) dapat berjalan pada ruangan tersebut, maka import FPSController pada asset "characters" yang telah disediakan Unity. Adanya tambahan code agar FPS dapat berjalan pada platform android pada script FirstPersonController, yaitu code CrossPlatformInputManager pada method Start(). Berikut hasil dari pembuatan scene menu utama. 


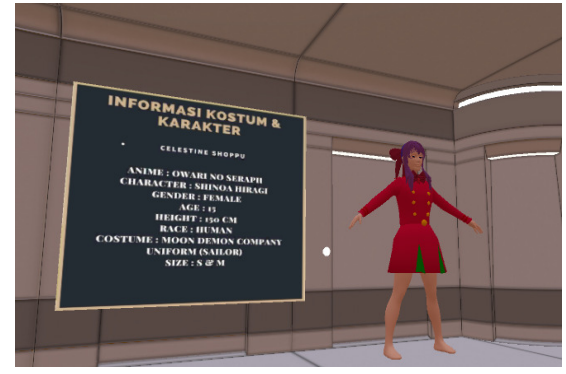

Gambar 7. Scene Toko Cosplay

Pembuatan scene about cosplay menggunakan lingkungan toko virtual yang sama pada scene toko cosplay. Peneliti menggunakan canva dalam membuat gambar mengenai penjelasan cosplay yang kemudian dimasukkan ke canvas. Pada scene ini, pengguna dapat berjalan dalam ruangan toko cosplay dengan adanya penjelasan mengenai cosplay, cosplayer, jenis-jenis cosplay, make up cosplay, dan tips cosplay. Jika pengguna ingin keluar dari ruangan tersebut maka menuju canvas exit. Berikut adalah hasil dari pembuatan scene about cosplay.

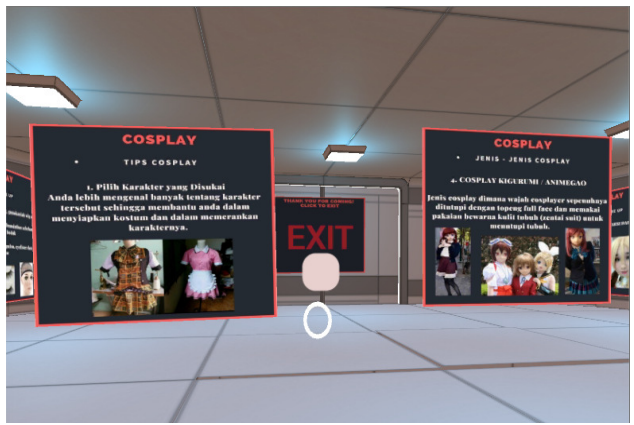

Gambar 8. Scene About Cosplay

Pembuatan scene menu mix \& match menggunakan button, canvas, dan model karakter dan kostum yang telah dibuat. Scene untuk mix \& match perempuan terdiri dari tombol male untuk menuju ke scene laki-laki, tombol previous dan next bagian atas untuk memilih pakaian bagian atasan, tombol previous dan next bagian bawah untuk memilih pakaian bagian bawahan, tombol back untuk kembali ke menu. Kemudian script yang digunakan yaitu MixMatchManager yang berisi function start() digunakan untuk memanggil fungsi setActiveAsset dan menampilkan tulisan "test" untuk melihat apakah fungsi berjalan, function setActiveAsset() digunakan untuk mengecek asset yang sedang aktif dijalankan, function NextAsset() digunakan untuk fungsi tombol ">" atau next untuk mengaktifkan asset selanjutnya, function PreviousAsset() digunakan untuk fungsi tombol "<" atau previous untuk mengaktifkan asset sebelumnya menggunakan looping. Berikut adalah hasil dari pembuatan scene mix \& match perempuan.

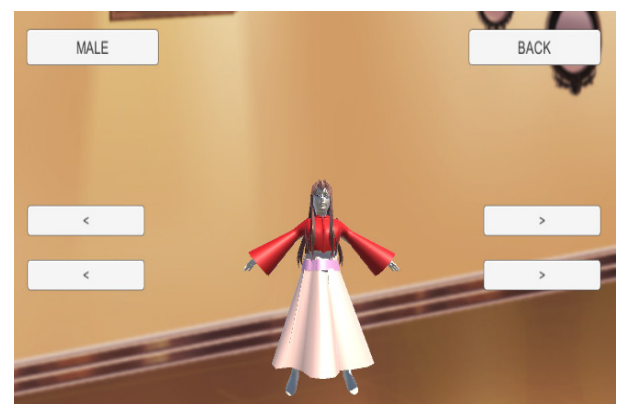

Gambar 9. Scene Mix \& Match Perempuan

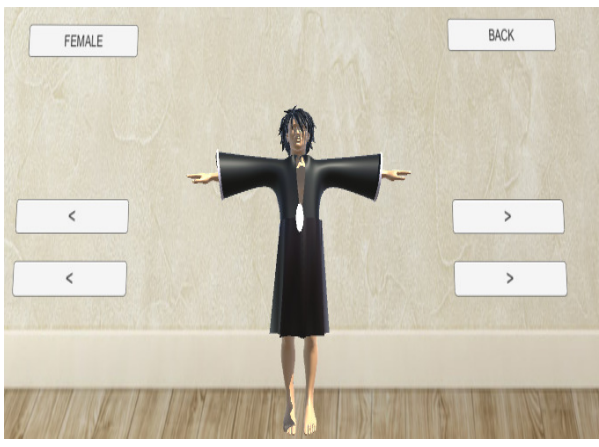

\section{Gambar 10. Scene Mix \& Match Perempuan}

Scene untuk mix \& match laki-laki terdiri dari tombol female untuk menuju ke scene perempuan, tombol previous dan next bagian atas untuk memilih pakaian bagian 
atasan, tombol previous dan next bagian bawah untuk memilih pakaian bagian bawahan, tombol back untuk kembali ke menu. Scene ini juga menggunakan code yang sama dengan scene mix and match perempuan yaitu MixMatchManager untuk melakukan pemilihan kostum. Berikut adalah hasil dari pembuatan scene mix \& match laki-laki.

\section{Pengujian}

Pada tahap evaluasi, peneliti melakukan pengujian menggunakan pengujian black box. Pengujian digunakan untuk menguji semua fungsi dan interface, apakah setiap fungsi berjalan dengan benar. Hasil pengujian dapat dilihat pada Tabel 3.

Tabel 3. Pengujian Black Box

\begin{tabular}{|c|c|c|c|}
\hline $\begin{array}{c}\text { Keteranga } \\
\mathrm{n}\end{array}$ & Skenario & $\begin{array}{l}\text { Hasil yang } \\
\text { Diharapkan }\end{array}$ & Hasil \\
\hline $\begin{array}{l}\text { Menu } \\
\text { Utama }\end{array}$ & $\begin{array}{l}\text { Tombol } \\
\text { Display, Mix } \\
\text { \& match, } \\
\text { About } \\
\text { Cosplay, dan } \\
\text { Exit untuk } \\
\text { menuju ke } \\
\text { scene yang } \\
\text { lain. }\end{array}$ & $\begin{array}{l}\text { Ketika tombol } \\
\text { di klik maka } \\
\text { sistem } \\
\text { berhasil } \\
\text { pindah scene } \\
\text { menggunaka } \\
\text { n Pointer saat } \\
\text { mengklik } \\
\text { tombol } \\
\text { joystick. }\end{array}$ & $\begin{array}{c}\text { Vali } \\
\text { d }\end{array}$ \\
\hline $\begin{array}{l}\text { Scene } \\
\text { Test_Map }\end{array}$ & $\begin{array}{l}\text { Berjalan } \\
\text { menggunaka } \\
\mathrm{n} \text { joystick }\end{array}$ & $\begin{array}{l}\text { Pengguna } \\
\text { dapat } \\
\text { berjalan } \\
\text { dengan sudut } \\
\text { pandang } \\
\text { orang } \\
\text { pertama } \\
\text { (First Person) } \\
\text { untuk } \\
\text { mengelilingi } \\
\text { dalam } \\
\text { ruangan } \\
\text { cosplay. }\end{array}$ & $\begin{array}{l}\text { Vali } \\
\text { d }\end{array}$ \\
\hline $\begin{array}{l}\text { Scene } \\
\text { Test_Map }\end{array}$ & Tombol Exit & $\begin{array}{l}\text { Pengguna } \\
\text { keluar dari } \\
\text { menu display } \\
\text { dan menuju } \\
\text { ke menu }\end{array}$ & $\begin{array}{l}\text { Vali } \\
\text { d }\end{array}$ \\
\hline
\end{tabular}

\begin{tabular}{|c|c|c|c|}
\hline & & utama & \\
\hline $\begin{array}{l}\text { Scene } \\
\text { Cosplay }\end{array}$ & $\begin{array}{l}\text { Digunakan } \\
\text { untuk melihat } \\
\text { scene about } \\
\text { cosplay }\end{array}$ & $\begin{array}{l}\text { Menampilkan } \\
\text { penjelasan } \\
\text { berupa teks } \\
\text { dan gambar } \\
\text { mengenai } \\
\text { cosplay }\end{array}$ & $\begin{array}{c}\text { Vali } \\
\text { d }\end{array}$ \\
\hline $\begin{array}{l}\text { Scene } \\
\text { MixMatch }\end{array}$ & $\begin{array}{l}\text { Tombol ">", } \\
\text { dan tombol } \\
\text { “<" dapat } \\
\text { ditekan untuk } \\
\text { memilih } \\
\text { pakaian } \\
\text { perempuan }\end{array}$ & $\begin{array}{l}\text { Ketika tombol } \\
\text { ">" ditekan } \\
\text { maka menuju } \\
\text { ke pakaian } \\
\text { perempuan } \\
\text { selanjutnya, } \\
\text { dan ketika } \\
\text { tombol “<" } \\
\text { ditekan maka } \\
\text { menuju ke } \\
\text { pakaian } \\
\text { perempuan } \\
\text { sebelumnya. }\end{array}$ & $\begin{array}{c}\text { Vali } \\
\text { d }\end{array}$ \\
\hline $\begin{array}{l}\text { Scene } \\
\text { Male }\end{array}$ & $\begin{array}{l}\text { Tombol ">", } \\
\text { dan tombol } \\
\text { "<" dapat } \\
\text { ditekan untuk } \\
\text { memilih } \\
\text { pakaian laki - } \\
\text { laki }\end{array}$ & $\begin{array}{l}\text { Ketika tombol } \\
\text { ">" ditekan } \\
\text { maka menuju } \\
\text { ke pakaian } \\
\text { pria } \\
\text { selanjutnya, } \\
\text { dan Ketika } \\
\text { tombol "<" } \\
\text { ditekan maka } \\
\text { menuju ke } \\
\text { pakaian pria } \\
\text { sebelumnya. }\end{array}$ & $\begin{array}{c}\text { Vali } \\
\text { d }\end{array}$ \\
\hline $\begin{array}{l}\text { Tombol } \\
\text { Male }\end{array}$ & $\begin{array}{l}\text { Dapat } \\
\text { ditekan untuk } \\
\text { berpindah ke } \\
\text { scene male }\end{array}$ & $\begin{array}{l}\text { Ketika tombol } \\
\text { male ditekan } \\
\text { maka menuju } \\
\text { ke scene } \\
\text { male, untuk } \\
\text { melakukan } \\
\text { mix \& match } \\
\text { kostum laki - } \\
\text { laki }\end{array}$ & $\begin{array}{c}\text { Vali } \\
\text { d }\end{array}$ \\
\hline $\begin{array}{l}\text { Tombol } \\
\text { Female }\end{array}$ & $\begin{array}{l}\text { Dapat } \\
\text { ditekan untuk } \\
\text { berpindah ke } \\
\text { scene } \\
\text { MixMatch }\end{array}$ & $\begin{array}{l}\text { Ketika tombol } \\
\text { female } \\
\text { ditekan maka } \\
\text { menuju ke } \\
\text { scene } \\
\text { mixMatch, } \\
\text { untuk } \\
\text { melakukan } \\
\text { mix \& match } \\
\text { kostum } \\
\text { perempuan. }\end{array}$ & $\begin{array}{c}\text { Vali } \\
\text { d }\end{array}$ \\
\hline
\end{tabular}




\begin{tabular}{l|l|l|c|}
\hline $\begin{array}{l}\text { Tombol } \\
\text { Exit }\end{array}$ & $\begin{array}{l}\text { Digunakan } \\
\text { untuk keluar } \\
\text { dari aplikasi }\end{array}$ & $\begin{array}{l}\text { Ketika tombol } \\
\text { exit ditekan } \\
\text { maka akan } \\
\text { keluar dari } \\
\text { aplikasi }\end{array}$ & $\begin{array}{c}\text { Vali } \\
\mathrm{d}\end{array}$ \\
\hline $\begin{array}{l}\text { Tombol } \\
\text { Back }\end{array}$ & $\begin{array}{l}\text { Digunakan } \\
\text { untuk } \\
\text { kembali ke } \\
\text { menu } \\
\text { sebelumnya }\end{array}$ & $\begin{array}{l}\text { Ketika tombol } \\
\text { back ditekan } \\
\text { akan menuju } \\
\text { ke scene } \\
\text { sebelumnya }\end{array}$ & $\begin{array}{c}\text { Vali } \\
\mathrm{d}\end{array}$ \\
\hline
\end{tabular}

\section{HASIL DAN PEMBAHASAN}

Aplikasi pemodelan cosplay yang telah dibuat dimuat kedalam Android Package (.apk) yaitu format untuk memasang aplikasi ke telepon pintar dengan sistem operasi Android. Aplikasi ini digunakan pada telepon pintar Android dengan minimal sistem operasi Android 4.4 KitKat. Telepon pintar tersebut juga harus dilengkapi dengan sensor Gyroscope. Pengguna perlu menggunakan kacamata Google Cardboard untuk masuk ke dalam lingkungan virtual dan Controller $V R /$ Joystick yang digunakan untuk pergerakan dan berjalan padsa aplikasi.

\section{A. Tampilan Aplikasi}

Jika aplikasi di jalankan maka akan menampilkan output seperti gambar 11 berikut ini:

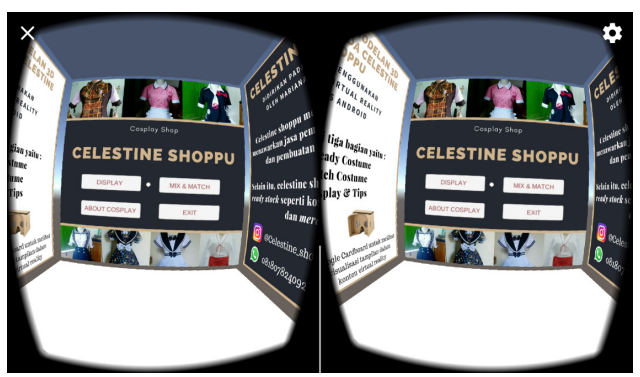

Gambar 11. Tampilan Scene Menu Awal

Dapat dilihat pada gambar 11, tampilan menu utama yang berisikan menu utama yaitu terdapat gambar, tombol display untuk menuju ke scene toko cosplay, tombol about cosplay untuk menuju ke scene informasi cosplay, tombol mix \& match untuk menuju ke scene mix and match kostum laki-laki dan perempuan, tombol Exit untuk keluar dari aplikasi.

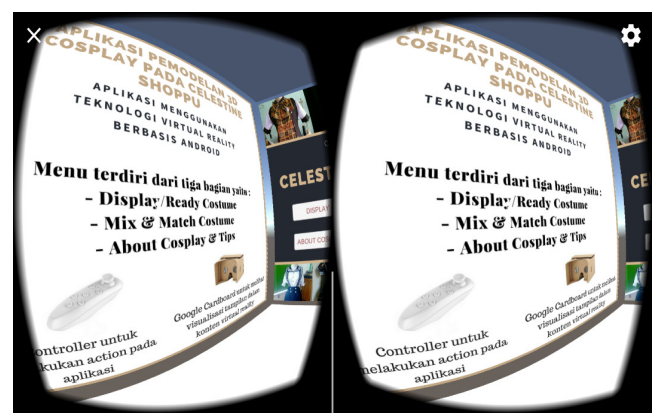

Gambar 12. Tampilan Informasi Aplikasi

Pada sebelah kiri menu terdapat tampilan informasi mengenai aplikasi pemodelan 3D seperti ditunjukan pada gambar 13 .

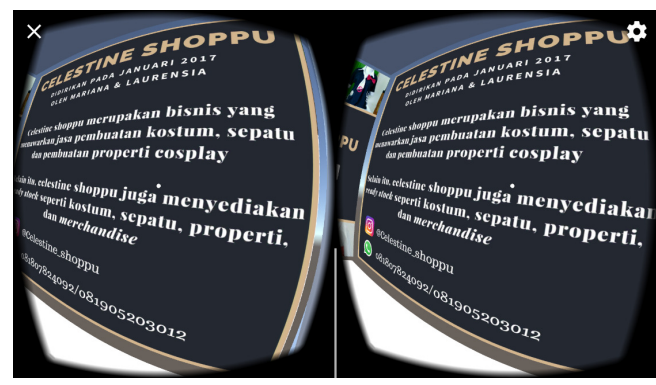

\section{Gambar 13. Tampilan Informasi Toko}

Kemudian pada sebelah kanan menu terdapat tampilan informasi mengenai toko peneliti yaitu Celestine Shoppu seperti ditunjukkan pada gambar 14 .

Pada gambar 14 merupakan tampilan scene display atau toko cosplay dimana pengguna berjalan dalam ruangan, terdapat berbagai macam manekin berupa karakter anime dan kostumnya yang disertai dengan adanya penjelasan 
informasi kostum dan karakter pada setiap manekin

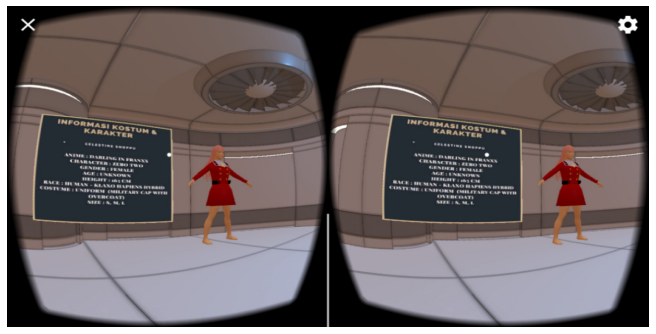

Gambar 14. Tampilan Scene Display

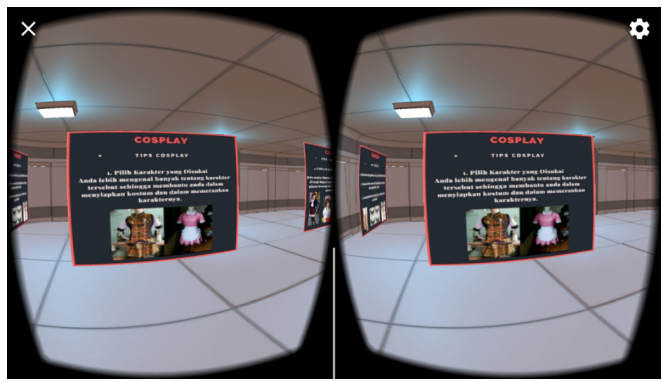

\section{Gambar 15. Tampilan Scene About} Cosplay

Pada gambar 15 merupakan tampilan scene about cosplay dimana pengguna berjalan dalam ruangan dan adanya penjelasan mengenai informasi cosplay, cosplayer, jenis-jenis cosplay, tips cosplay bagi pemula dan make up cosplay.

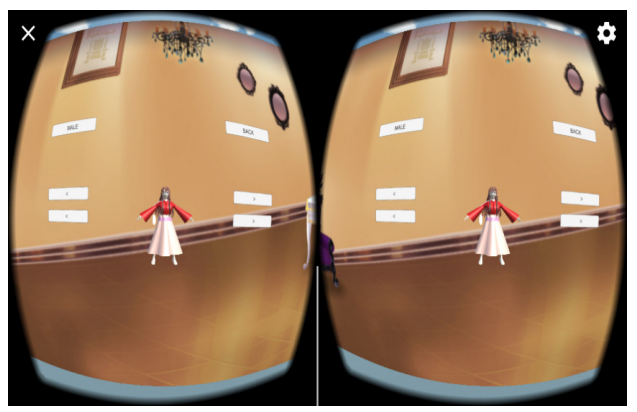

Gambar 16. Tampilan Scene Mix \& Match Perempuan

Pada gambar 16 merupakan scene mix and match kostum perempuan, pengguna dapat memilih pakaian berupa atasan dan bawahan dengan klik tombol ">" untuk ke pakaian selanjutnya dan tombol "<" untuk ke pakaian sebelumnya. Klik tombol back untuk kembali ke menu utama dan tombol male untuk menuju scene mix and match untuk laki - laki.

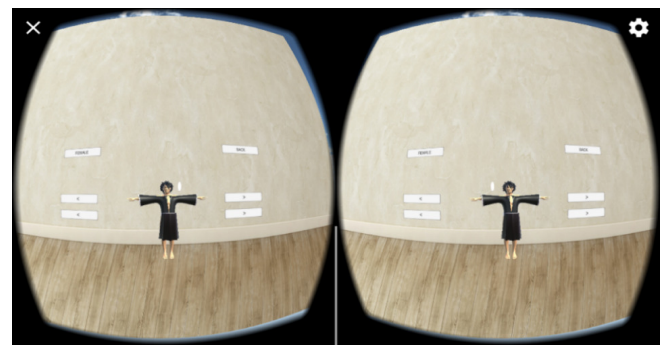

Gambar 17. Tampilan Scene Mix \& Match Laki-Laki

Pada gambar 17 merupakan scene mix and match kostum laki-laki, pengguna dapat memilih pakaian berupa atasan dan bawahan dengan klik tombol ">" untuk ke pakaian selanjutnya dan tombol "<" untuk ke pakaian sebelumnya. Klik tombol back untuk kembali ke menu utama dan tombol female untuk ke scene mix and match untuk perempuan.

\section{B. Evaluasi}

Jenis kostum dan animasi perlu ditambahkan pada model karakter, namun tidak dapat terealisasikan karena keterbatasan teknologi yang dimiliki oleh peneliti, karena untuk membuat jenis kostum yang banyak dengan adanya animasi diperlukan spesifikasi komputer yang tinggi.

Pada penelitian yang terhadulu, aplikasi pemodelan baju dan pembuatan tubuh manusia menggunakan teknologi CAD (Computer Aided Design) dan aplikasi hanya digunakan pada desktop, sehingga yang membedakan dengan aplikasi yang dikembangkan oleh peneliti yaitu dalam 
pembuatan pemodelan 3D kostum dan karakter dapat menggunakan Blender serta aplikasi dikembangkan menggunakan Unity 3D, kemudian manekin yang digunakan menggunakan model karakter anime dengan adanya kostum dari karakter tersebut, dan aplikasi dijalankan pada telepon pintar berbasis Android.

\section{Hasil Pengujian Pengguna}

Pengujian user experience (UX) dilakukan untuk mengetahui timbal balik atau feedback dari pengguna dalam menguji aplikasi pemodelan cosplay. Pengujian ini dilakukan dengan meminta 20 responden yang merupakan pengunjung event atau festival Jepang pada tanggal 24 Juni 2018. Pengunjung terdiri dari remaja dan dewasa cosplayer maupun bukan cosplayer.

Bedasarkan hasil pengujian tersebut, timbal balik yang diberikan oleh pengguna setelah menggunakan aplikasi yaitu:

- Pemodelan 3D karakter dan kostum pada aplikasi menarik, namun masih terlihat kaku.

- Informasi mengenai cosplay, kostum dan karakter tersampaikan dengan baik dan jelas.

- Pengguna cukup nyaman dalam menggunakan aplikasi.

- Pengguna berpendapat bahwa aplikasi membantu dalam melakukan mix and match kostum, namun jenis kostum perlu ditambahkan.

\section{SIMPULAN}

Berdasarkan hasil implementasi dan pengujian pada penelitian ini, maka dapat disimpulkan sebagai berikut:

- Teknologi Virtual Reality (VR) dapat digunakan sebagai alternatif visualisasi karakter anime dan kostum cosplay, serta untuk melakukan mix and match kostum untuk cosplay original character.

- Aplikasi pemodelan cosplay memiliki tiga menu yaitu menu display untuk melihat pemodelan 3D karakter dan kostum, menu about cosplay untuk melihat informasi cosplay, dan menu mix \& match untuk melakukan mix and match kostum original character laki - laki dan perempuan.

- Pada unity versi 2017.1.1f1, unity tidak dapat melakukan proses build menjadi APK karena unity belum support ketika menggunakan tools SDK dan JDK android terbaru, maka tools SDK yang digunakan menjadi r25.2.5 dan jdk 1.8.0_171.

- Aplikasi hanya dapat digunakan pada smartphone berbasis android yang memiliki gyroscope dengan sistem operasi minimum Android 4.4 Kit Kat.

- Bedasarkan hasil dari pengujian user experience, pengunjung merasa aplikasi bermanfaat dan dibutuhkan pada festival Jepang, namun desain model karakter masih kaku dan perlu diperbaiki.

\section{DAFTAR PUSTAKA}

[1]R. Rastati, 2012. "Media dan Identitas: Cultural Imperialism Jepang," Jurnal Komunikasi Indonesia, Vol. 1 No. 2.

[2]M. Dasbatz, 2014. Designing Interactive Multimedia Systems, McGraw-Hill.

[3] J. Rori, S. . Sentinuwo and S. Karouw, 2016 Perancangan Aplikasi Panduan Belajar Pengenalan Ortodonsia Menggunakan Animasi," Journal Teknik Informatika, Vols. 8, No.1J. Glover, 2016. Unity Programming for Human Beings, Zenva. 